\title{
Adjustable Versus Nonadjustable Sutures in Strabismus Surgery-Who Benefits the Most?
}

\author{
Maciej Gawęcki (D) \\ Dobry Wzrok Ophthalmological Clinic, Kliniczna 1B/2, 80-402 Gdansk, Poland; gawecki@use.pl; \\ Tel.: +48-501-788654
}

Received: 22 December 2019; Accepted: 21 January 2020; Published: 21 January 2020

\begin{abstract}
Background: Adjustable sutures have been used in strabismus surgery for more than 40 years, but controversy remains regarding their application. This review sought to analyze studies comparing the efficacy of adjustable sutures (AS) and nonadjustable sutures (NAS) in the treatment of different ocular deviations. Materials and Methods: The PubMed literature database was searched using the keywords 'adjustable sutures' and 'strabismus surgery', yielding a total of 209 results. Only comparative studies were extracted, and the results were divided into three categories: Adult comitant strabismus, childhood comitant strabismus, and paretic/restrictive strabismus. Results: The search revealed eleven comparative studies on AS versus NAS in adult strabismus, including only one randomized controlled trial. Five of these studies analyzed just the postoperative success rate, three studies analyzed just the reoperation rate, two studies analyzed both the postoperative success and reoperation rates, and one study evaluated achievement of the postoperative target angle. Three of seven studies analyzing postoperative success reported the statically significant superiority of AS over NAS, while four of five studies analyzing reoperation rate indicated a significantly smaller percentage of reoperations with the use of AS. The study covering postoperative target angle as an outcome favored the AS technique. Separately, the search revealed three comparative studies on AS versus NAS in childhood strabismus, one of which reported a statistically significant advantage with AS. Only four comparative studies on AS versus NAS in paretic or restrictive strabismus were found; all showed a tendency for better results with the use of AS but not in a statistically significant fashion. Overall, out of 18 studies analyzed in this review, 17 suggested better clinical results followed the application of AS versus NAS; however, only a minority had statistically significant results. Conclusion: The analysis of available research failed to support AS as the preferable surgery technique over NAS in cases of simple and predictive strabismus. Further research is needed to more precisely determine the group of patients able to benefit the most from AS.
\end{abstract}

Keywords: adjustable sutures; strabismus surgery; paretic strabismus

\section{Introduction}

Adjustable sutures (AS) have been used in strabismus surgery for a few decades since their first description by Jampolsky in 1974; however, controversy remains regarding their application in clinical practice [1]. Many surgeons advocate for AS during surgery for the management of most cases of strabismus, while others limit their use to when treating adults or in selected complicated cases such as paralytic strabismus, restrictive strabismus, and reoperations [2].The question of careful selection of patients suitable for AS is often brought up [3]. AS surgery is reported to be used less frequently than classic nonadjustable sutures (NAS). According to the Intelligent Research in Sight registry of the American Academy of Ophthalmology, AS were used in $7.42 \%$ of strabismus surgery cases [4]. Some clinicians do not see the advantage of adopting AS over NAS in every patient, especially in cases of simple comitant strabismus. They also point out that the adjustment procedure is uncomfortable 
and stressful for the patient and requires special nursing care [5]. Interestingly, Vassconcelos and Guyton in their editorial for Arquivos Brasilerios de Oftalmologia indicated that the adoption of AS in strabismus surgery is partly related to surgical experience [6]. Successful use of AS requires a long apprenticeship and often promotes a high load of stress at the beginning of the learning curve, so some surgeons favor the simpler NAS technique.

This study sought to review the medical literature covering the results of both techniques to elucidate the group of patients who would benefit the most from the AS technique. This paper specifically concentrated on studies that presented results of AS versus NAS surgery in a comparative fashion.

\section{Materials and Methods}

The PubMed literature database was searched according to the keywords 'adjustable sutures' and 'strabismus surgery'. A total of 209 results were found, from which only comparative studies were extracted. Results of the search were divided into three groups according to subject matter: Comitant deviation in adults, comitant deviation in children, and paralytic or restrictive strabismus.

Ethical statement: The study had a character of a review, so formal consent for its conducting was not needed.

\section{Results}

Of the 18 studies ultimately selected for inclusion in this review, the database search revealed just two randomized controlled trials (RCT) comparing the results of AS versus NAS [7,8]. The first study included 60 children with an average age of 3.5 randomized into AS and NAS groups, respectively. Adjustment was performed usually a few hours after surgery under propofol. Success was defined as a final deviation of 8 prism diopters or less of straight at six months and was achieved in $88.67 \%$ of the AS group versus $73.33 \%$ of the NAS group. The authors thus reported the results favored AS as clinically preferable, although the difference between the techniques was not statistically significant.

The second study involved 40 adults with intermittent exotropia. Similarly, there was no significant difference found between AS versus NAS regarding the postoperative success rate (90\% for AS vs. $85 \%$ for NAS; $p=0.3$ ). The details of these studies are presented in Tables 1 and 2.

Altogether, we identified 11 comparative studies that reported on AS versus NAS in adult strabismus surgery, including one of the RCTs mentioned above. Five of these studies analyzed just the postoperative success rate, three studies analyzed just the reoperation rate, two studies analyzed both the postoperative success and reoperation rates, and one study evaluated the achievement of the postoperative target angle. The results of these studies are presented in Table 1.

\subsection{Postoperative Success Rate}

Seven studies altogether analyzed the postoperative success rate in AS versus NAS, usually at three to six months after surgery.

Only three studies suggested statistically better results of surgery were achieved with the use of AS [9-11]. The remaining four studies did not prove the statistical superiority of either of the two surgical methods over the other [8,12-14].

One study concentrated on achievement of the target postoperative angle and, in that respect, strongly favored AS over NAS for both horizontal and vertical deviations [15].

\subsection{Reoperation Rate}

Three studies concentrated solely on evaluating the reoperation rate in AS versus NAS [16-18] and two analyzed both the postoperative success rate and the reoperation rate [10,11]. Two of these studies, both by Leffer and colleagues, suggested a lower reoperation rate was achievable with the use of AS in horizontal strabismus but not vertical strabismus [16,17]. Studies by Tripathi et al. [18] and Zhang et al. [11] favored AS independently of deviation type, while the study by Mireskandari 
et al. [10] did not report a statistically significant difference in reoperation rate between the AS and NAS techniques.

Only one study —on sensory exotropia-showed better clinical results were attainable using NAS, without statistical significance. All other included studies reported clinically better results were obtained with the use of AS, although this result was not backed by statistical significance either.

Separately, the review of the medical literature revealed just three comparative studies on AS versus NAS in children. The results of the search in this regard are presented in Table 1.

A large study by Kassem et al. ( $n=637$ patients) showed the superiority of AS over NAS in achieving the expected postoperative deviation [19]. On the other hand, the aforementioned RCT by Kamal et al. did not prove that effect, although their sample population was much smaller $(n=60$ patients) [7]. A study by Leffer et al. concentrated on the reoperation rate in AS and NAS but did not reveal any statistically significant difference between the two groups [20]. Again, as seen among adults, the latter two studies clinically favored the AS technique, but without statistical significance.

There were very few studies available that compared the efficacy of AS versus NAS in paralytic and restrictive strabismus. The results of the search in this regard are presented in Table 3.

The available research does not favor AS if statistical significance is the only criterion; however, some clinical results suggest a tendency for better postoperative outcomes with the use of AS [2,21]. Nevertheless, the possibility of substantial postoperative drift must be taken into consideration when using AS in vertical strabismus [22]. 
Table 1. Studies comparing the effects of treatment according to AS versus NAS.

\begin{tabular}{|c|c|c|c|c|}
\hline Author & Material and Study Design & Type of Deviation Analyzed & Results & Statistical Significance \\
\hline $\begin{array}{l}\text { Babu et al. } \\
\quad[3] .\end{array}$ & $\begin{array}{l}\text { Randomized, prospective, interventional } \\
40 \text { adults with intermittent exotropia } \\
\text { randomized either to AS ( } 20 \text { eyes) or NAS } \\
\text { (20 eyes) technique for bilateral LR } \\
\text { recession. }\end{array}$ & Intermittent exotropia. & $\begin{array}{c}\text { Success defined as postoperative deviation } \\
<10 \text { PD } \\
\text { Evaluation at } 12 \text { weeks: } \\
\text { Success in 90\% of patients in AS group and } 85 \% \\
\text { in NAS group. } \\
\text { Mean residual deviation in AS group: } 6.2 \mathrm{PD} \text {, in } \\
\text { NAS group: 5.6 PD. }\end{array}$ & $p=0.316$; difference insignificant. \\
\hline $\begin{array}{l}\text { Ferdi A et al. } \\
\quad[12]\end{array}$ & $\begin{array}{c}27 \text { consecutive patients operated at one } \\
\text { hospital; } 11 \text { AS, } 16 \text { NAS. } \\
\text { Out of } 11 \text { AS patients, only } 6 \text { had } \\
\text { adjustment made. }\end{array}$ & Horizontal. & $\begin{array}{l}\text { Mean postoperative deviation: 11.6 PD in AS } \\
\text { group and 15.3 PD in NAS group. }\end{array}$ & $\begin{array}{l}\text { Postoperative deviation: } p=0.519 \\
\text { difference insignificant. }\end{array}$ \\
\hline $\begin{array}{l}\text { Leffler CT et } \\
\text { al. [16] }\end{array}$ & $\begin{array}{l}\text { Reoperation rate in AS and NAS group } \\
\text { during one calendar year. } \\
\text { Analysis of fee-for-service payments to } \\
\text { Medicare in 2012. } \\
\end{array}$ & Horizontal and vertical. & $\begin{array}{c}\text { Reoperation rate for horizontal strabismus: } 4.1 \% \\
(15 / 364) \text { for AS and } 7.1 \%(77 / 1,082) \text { for NAS. } \\
\text { In vertical strabismus: } 4.1 \%(8 / 196) \text { for AS and } \\
8.3 \%(38 / 458) \text { for NAS. }\end{array}$ & $\begin{array}{c}p=0.047 \text { for horizontal strabismus and } \\
p=0.07 \text { for vertical strabismus. } \\
\text { Difference significant for horizontal } \\
\text { strabismus. }\end{array}$ \\
\hline $\begin{array}{c}\text { Agrawal et al. } \\
\text { [9] }\end{array}$ & $\begin{array}{l}\text { Prospective, comparative, nonrandomized } \\
\text { study. } \\
54 \text { patients with horizontal strabismus } \\
\text { operated with AS (27) or NAS (27). }\end{array}$ & Horizontal. & $\begin{array}{c}\text { Success defined as postoperative deviation } \\
\text { within } \pm 10 \text { PD at } 6 \text { months. } \\
\text { Success rate: } 88.8 \% \text { ( } 24 \text { patients) in AS group and } \\
62.9 \% \text { (17 patients) in NAS group. }\end{array}$ & $p=0.02$, statistically significant. \\
\hline $\begin{array}{l}\text { Leffler et al. } \\
\quad[17]\end{array}$ & $\begin{array}{c}\text { Retrospective, review of insurance } \\
\text { database 2007-2011. } \\
\text { Reoperation rate among } 6178 \text { strabismus } \\
\text { surgeries in adults according to AS or NAS } \\
\text { technique. }\end{array}$ & Horizontal and vertical. & $\begin{array}{c}\text { Total reoperation rate: } 8.5 \% \\
\text { AS group: } 8.1 \% \text { vs. NAS group: } 8.6 \% \text {. } \\
\text { For horizontal deviations, reoperation rate } 5.8 \% \\
\text { in AS group and } 7.8 \% \text { in NAS group. } \\
\text { For vertical deviations, reoperation rate } 15.2 \% \text { in } \\
\text { AS group and } 10.4 \% \text { in NAS group. }\end{array}$ & $\begin{array}{c}\text { For total reoperation rate: } p=0.57, \\
\text { difference insignificant. } \\
\text { For horizontal strabismus: } p=0.02, \\
\text { difference significant. } \\
\text { For vertical deviations: } p=0.05 \\
\text { borders on statistical significance. }\end{array}$ \\
\hline $\begin{array}{l}\text { Mireskandari } \\
\text { et al. [15] }\end{array}$ & $\begin{array}{c}\text { Retrospective. } \\
353 \text { patients older than } 12 \text { years. } \\
\text { Chances of achieving target postoperative } \\
\text { deviation with AS versus NAS. } \\
\text { Target deviation: for esotropia and vertical, } \\
\text { within } 4 \text { PD; for exotropia, between } \\
\text { orthotropia and } 8 \text { PD esotropia }\end{array}$ & Horizontal and vertical. & $\begin{array}{l}\text { AS group achieved target angle in } 75.5 \% \text { cases } \\
\text { versus } 54 \% \text { in NAS group. }\end{array}$ & $p<0.0001$, statistically significant. \\
\hline $\begin{array}{l}\text { Liebermann } \\
\text { et al. [13] }\end{array}$ & $\begin{array}{c}\text { Retrospective. } \\
89 \text { consecutive patients operated with AS } \\
60 \% \text { (53) adjusted. } \\
40 \% \text { (36) tied off (good effect during } \\
\text { adjustment). }\end{array}$ & Horizontal, reoperation. & $\begin{array}{l}\text { Long-term results (success if deviation }<10 \mathrm{PD} \\
\text { and no diplopia): } \\
\text { Success rate at } 6 \text { weeks: } 64 \% \text { for not adjusted and } \\
81 \% \text { for adjusted. } \\
\text { At 1-year success rate: } 67 \% \text { for not adjusted and } \\
\quad 77 \% \text { for adjusted. }\end{array}$ & $\begin{array}{c}p=0.09 \text { for } 6 \text { weeks and } p=0.3 \text { for } \\
1 \text { year. } \\
\text { Difference not significant. }\end{array}$ \\
\hline
\end{tabular}


Table 1. Cont

\begin{tabular}{|c|c|c|c|c|}
\hline Author & Material and Study Design & Type of Deviation Analyzed & Results & Statistical Significance \\
\hline $\begin{array}{l}\text { Mireskandari } \\
\text { et al. [10] }\end{array}$ & $\begin{array}{l}\text { Retrospective, data from } 13 \text { years, } \\
\text { one surgeon. } \\
144 \text { patients; primary operations } \\
\text { and reoperations. }\end{array}$ & Horizontal and vertical. & $\begin{array}{c}\text { Success defined as postoperative deviation } \\
\text { within } 10 \text { PD for horizontal and } 5 \text { PD for vertical } \\
\text { strabismus, lack of diplopia. } \\
\text { Success rate: } 77.7 \% \text { for AS and } 65.9 \% \text { for NAS. } \\
\text { For exotropia, success rate: AS } 80.8 \% \text { for AS } \\
\text { versus } 65.9 \% \text { for NAS. } \\
\text { For primary surgery success rate: } 82.5 \% \text { for AS } \\
\text { versus } 50 \% \text { for NAS. } \\
\text { Reoperation: } 80.2 \% \text { for AS and } 77.6 \% \text { for NAS. }\end{array}$ & $\begin{array}{l}\text { For overall: } p=0.059, \text { not significant. } \\
\text { For exotropia: } p=0.011, \text { significant. } \\
\text { For primary surgery: } p=0.003, \\
\text { significant. } \\
\text { For reoperations: } p=0.71 \text {, not } \\
\text { significant. }\end{array}$ \\
\hline $\begin{array}{l}\text { Zhang et al. } \\
\text { [11] }\end{array}$ & $\begin{array}{l}\text { Retrospective, data from 1989-2013. } \\
535 \text { consecutive strabismus patients; } \\
\text { included } 491 \text { patients: } 305 \text { AS and 186 NAS. }\end{array}$ & Horizontal and vertical. & $\begin{array}{c}\text { Success: postoperative deviation } \leq 10 \text { PD } \\
\text { horizontal and } \leq 2 \text { PD vertical. } \\
\text { Follow-up: } 7 \text { days to } 12 \text { weeks. } \\
\text { Overall success rate: } 74.8 \% \text { for AS and } 61.3 \% \text { for } \\
\text { NAS. } \\
\text { Reoperations success rate: } 65.7 \% \text { for AS versus } \\
42.4 \% \text { for NAS. } \\
\text { Childhood strabismus primary success rate: } \\
81.4 \% \text { for AS versus } 65 \% \text { for NAS. } \\
\text { TO success rate: } 74.1 \% \text { for AS versus } 76.7 \% \text { for } \\
\text { NAS. }\end{array}$ & $\begin{array}{l}\text { Overall: } p=0.0016 \text {, significant. } \\
\text { Reoperations: } p=0.03 \text {, significant. } \\
\text { Childhood primary: } p=0.135 \\
\text { insignificant. } \\
\text { TO } p=0.82, \text { insignificant. }\end{array}$ \\
\hline $\begin{array}{l}\text { Park et al. } \\
\quad[14]\end{array}$ & $\begin{array}{c}\text { Retrospective, data from 1998-2005 } \\
54 \text { patients with sensory exotropia; } 34 \\
\text { operated with NAS, } 20 \text { operated with AS } \\
\text { on LR. }\end{array}$ & Sensory exotropia. & $\begin{array}{l}\text { Postoperative success defined as deviation }<15 \\
\text { PD at } 3 \text { months. } \\
\text { Success: } 75 \% \text { (15 patients) in AS group versus } \\
88 \% \text { ( } 30 \text { patients) in NAS group. }\end{array}$ & $p=0.944$, not significant. \\
\hline $\begin{array}{c}\text { Tripathi et al. } \\
{[18]}\end{array}$ & $\begin{array}{c}\text { Retrospective, data from } 1996-2000 . \\
443 \text { patients older than } 13 \text { years. } \\
141 \text { operated with AS, } 302 \text { operated } \\
\text { with NAS. } \\
\text { Analysis of reoperation rate. }\end{array}$ & All types. & $\begin{array}{l}\text { Reoperation rate: } \\
\text { 8.51\% for AS and } 27.15 \% \text { for NAS. }\end{array}$ & $p<0.005$, significant. \\
\hline
\end{tabular}

AS: adjustable sutures; NAS: nonadjustable sutures; PD: prism diopters; LR: lateral rectus; IR: inferior rectus; TO: thyroid ophthalmopathy. 
Table 2. AS versus NAS in children.

\begin{tabular}{|c|c|c|c|c|c|}
\hline Author & Study Design and Material & Deviation Type & Type of Anesthesia & Results & Statistical Significance \\
\hline Kassem et al. [2] & $\begin{array}{c}\text { Retrospective analysis of records } \\
\text { of consecutive patients aged } \\
\leq 15 \text { years operated on from } 1989 \\
\text { through } 2012 . \\
\text { Material: } 521 \text { patients in AS } \\
\text { group and } 116 \text { patients in NAS } \\
\text { group. }\end{array}$ & Horizontal. & $\begin{array}{l}\text { Adjustment in proparacaine } \\
(15 \%) \text { and intravenous } \\
\text { propofol }(85 \%) .\end{array}$ & $\begin{array}{c}\text { Success defined as deviation } \\
\text { within 8PD of straight at } \\
\text { 3-6 months: } \\
77.7 \% \text { in AS group } 64,6 \% \text { in NAS } \\
\text { group. }\end{array}$ & $p \leq 0.03$; significant. \\
\hline Kamal et al. [2]. & $\begin{array}{c}\text { RCT of AS versus NAS in } \\
\text { children. } \\
\text { Material: } 30 \text { eyes operated by AS, } \\
\text { mean age } 3.48 \pm 2.37 \text { and } 30 \text { eyes } \\
\text { operated by NAS } 3.55 \pm 2.64 .\end{array}$ & Horizontal. & $\begin{array}{l}\text { Adjustment under Propofol; } \\
\text { mean } 156.5 \pm 46.6 \text { min. after } \\
\text { the main surgery. }\end{array}$ & $\begin{array}{c}\text { Success defined as final deviation } \\
\leq 8 \text { PD of straight at } 6 \text { months: } \\
88.67 \% \text { in AS group } 73.33 \% \text { in } \\
\text { NAS. } \\
\text { Over-correction } 13.33 \% \text { in AS } \\
\text { group versus } 3.33 \% \text { in NAS } \\
\text { group. } \\
\text { Under-correction } 0 \% \text { in AS versus } \\
23.33 \% \text { in NAS group. }\end{array}$ & $\begin{aligned} p= & 0.197 ; \text { statistically } \\
& \text { insignificant. }\end{aligned}$ \\
\hline Leffler et al. [20] & $\begin{array}{c}\text { Retrospective. } \\
\text { Analysis of insurance database } \\
\text { 2007-2013; reoperation rate in AS } \\
\text { and NAS technique. Material: } \\
\text { 11,115 documented strabismus } \\
\text { operations in patients under } \\
18 \text { years of age. }\end{array}$ & All types. & Not analyzed. & $\begin{array}{c}\text { Total reoperation rate: } 7.7 \% \text {. } \\
\text { Specifically, in AS group: } 7.4 \% \text {, in } \\
\text { NAS group: } 9.6 \% .\end{array}$ & $\begin{array}{c}p=0.18 ; \text { difference } \\
\text { statistically insignificant. }\end{array}$ \\
\hline
\end{tabular}

AS: adjustable sutures; NAS: nonadjustable sutures; PD: prism diopters; RCT: randomized controlled trial. 
Table 3. Paralytic or restrictive strabismus surgery.

\begin{tabular}{|c|c|c|c|c|}
\hline Author & Material and Study Design & Type of Deviation Analyzed & Results & Statistical Significance \\
\hline $\begin{array}{l}\text { Peragallo et } \\
\text { al. [2] }\end{array}$ & $\begin{array}{l}\text { Retrospective. } \\
\text { Material: } 56 \text { patients with III nerve palsy. } \\
\text { AS in } 27 \text { patients (48\%), NAS in } 29 \text { (52\%). }\end{array}$ & IIIrd nerve palsy. & $\begin{array}{l}\text { Success: postoperative deviation } \leq 10 \mathrm{PD} \\
\text { horizontal and } \leq 2 \mathrm{PD} \text { vertical. } \\
63 \% \text { for AS and } 38 \% \text { for NAS. }\end{array}$ & $p=0.06$, difference insignificant. \\
\hline $\begin{array}{l}\text { Peragallo et } \\
\text { al. [22] }\end{array}$ & $\begin{array}{l}\text { Retrospective, controlled. } \\
\text { Evaluation of IR recession and } \\
\text { postoperative drift in TO with the use of } \\
\text { AS versus NAS and confronted with } \\
\text { control group patients who underwent IR } \\
\text { recession due to other disorders than TO. }\end{array}$ & TO, hypotropia. & $\begin{array}{c}\text { AS group: before surgery: } 17 \mathrm{PD} \pm 9 \text {; Day } 1 \text { : } \\
1.2 \pm 2.5 \text {; final: }-0.7 \pm 5.6 \\
\text { NAS group before surgery: } 21 \pm 7 \text {; Day } 1 \text { : } \\
\text { 3.7 } \pm 4.9 \text {; final: } 2.7 \pm 6.7 \\
\text { Controls: before surgery } 11 \pm 4 \text {; Day } 1: 0.3 \pm 2.4 \\
\text { final } 1.7 \pm 5.7 \\
\text { Drift values: }-1.9 \pm 4.3 \text { for AS; }-1.0 \pm 4.6 \text { for } \\
\text { NAS; } 1.4 \pm 5.9 \text { for controls. }\end{array}$ & $\begin{array}{c}p=0.05 \text { for the drift between AS group } \\
\text { versus controls. }\end{array}$ \\
\hline $\begin{array}{l}\text { Karhanova et } \\
\text { al. [21] }\end{array}$ & $\begin{array}{l}\text { Retrospective. } \\
14 \text { patients with TO operated on with AS ( } \\
=7) \text { or NAS }(n=7) \text { technique. }\end{array}$ & $\mathrm{TO}$, restrictive. & $\begin{array}{l}\text { AS: no need for reoperation or prismatic } \\
\text { correction. } \\
\begin{array}{c}\text { NAS: } 2 \text { patients required reoperation and } 2 \\
\text { required prismatic correction. }\end{array}\end{array}$ & $\begin{array}{l}\text { Sample too small to show statistical } \\
\text { significance. }\end{array}$ \\
\hline $\begin{array}{l}\text { Kraus et al. } \\
\text { [23] }\end{array}$ & $\begin{array}{l}\text { Retrospective. } \\
37 \text { patients who underwent IR recession, } 26 \\
\text { NAS and } 11 \text { AS. }\end{array}$ & TO. & $\begin{array}{c}\text { Success defined as fusion in primary and reading } \\
\text { position without prisms. } \\
\text { Results: } \\
\text { AS: success in } 64 \%(7 / 11) \text { without prism, } 91 \% \\
(10 / 11) \text { with or without prisms. } \\
\text { NAS: success in } 38 \%(10 / 26) \text { without prism and } \\
65 \%(17 / 26) \text { with or without prism. } \\
\text { Reoperation rate: } \\
\text { AS: } 9 \%(1 / 11) \\
\text { NAS: } 35 \%(9 / 26)\end{array}$ & $\begin{aligned} p= & 0.279 \text { for success; } \\
p= & 0.224 \text { for reoperation rate; } \\
& \text { Not significant. }\end{aligned}$ \\
\hline
\end{tabular}

AS: adjustable sutures; NAS: nonadjustable sutures; PD: prism diopters; IR: inferior rectus; TO: thyroid ophthalmopathy. 


\section{Discussion}

The present analysis of available studies comparing the AS and NAS techniques does not yield statistically significant results that unequivocally favor the use of AS (or NAS) in any form of strabismus. Most of the studies that analyzed the reoperation rate in AS versus NAS showed, however, that the percentage of patients who require a second surgery is significantly lower following the use of AS.

The author believes that the interpretation of the results of clinical research on the subject of AS versus NAS must go beyond just statistics. Concentrating solely on RCTs will not provide any conclusions, as so far only two such studies were performed [7,8]. Authors of recent Cochrane Database Systemic Reviews on AS versus NAS in strabismus surgery were not able to present any reliable thesis due to the scarceness of randomized studies on the subject [24].

Many authors choose AS as their preferred procedure in treating complicated forms of strabismus, and thus do not perform any comparative studies with NAS. Besides, it should be emphasized that, generally, rates of postoperative success are high for both AS and NAS; thus, the statistical superiority of either of these two procedures over the other is hard to prove.

Almost all of the studies included (besides one on sensory exotropia) suggest the clinical superiority of AS versus NAS but not in a manner that reached statistical significance. This fact should not be ignored and could suggest that AS works better for certain groups of patients but not for all patients. It has to be taken into consideration that some deviations drift with time, no matter which surgical technique is used. As we see from the study by Mireskandari et al., AS is significantly better in achieving immediate postoperative success, but this was not necessarily a long-term effect [15]. With the more precise selection of patients for AS surgery, the statistical significance in many studies could more likely have been achieved.

It has to be said, that only a percentage of patients operated on with AS require adjustment. In the study by Weston et al. ( $n=201$ consecutive patients), just $40 \%$ of cases required suture adjustment, while the remaining $60 \%$ were simply tied off [25]. Agnello et al. reported a necessity for adjustment in $62.3 \%$ of their AS strabismus surgeries (48/77 patients) [26]. Pratt-Johnson et al. reported $48.2 \%$ $(123 / 255)$ of patients required adjustment in AS surgery cases [27]. However, this number was as low as $26 \%$ in the study of McNeer et al. (vertical strabismus) [28].

These data suggest that, on average, half of normal strabological measurements work well without the necessity for adjustment. In this context, research should focus on determining the patients who would benefit most from AS strabismus surgery without the necessity to adjust all of them. Considering AS to be a superior technique to NAS in treating simple forms of strabismus is questionable.

Most of the papers available in PubMed database are case series presenting optimistic results of AS surgery but not really comparing the results of strabismus surgery between AS and NAS [29,30]. Often, authors point out the beneficial role of AS in complicated cases of strabismus and the reduced need for reoperation with the use of the technique [31,32].

It should be emphasized that experienced ophthalmic surgeons who actually use AS are eager supporters of the technique and often tend to abandon NAS in most adult cases of strabismus. This explains why comparative studies on AS versus NAS are so sparse. However, followers of AS defend its superiority over classical strabismus surgery based on personal experience and clinical practice but not necessary RCTs.

The act of adjustment itself creates most of the controversies and arguments. Adversaries to AS usually bring up the patient's discomfort as a major problem seen during the AS procedure. Some clinicians believe that patients should be carefully selected according to their potential cooperation for the adjustment procedure [3,33]. Therefore, they exclude children as potential candidates. Adjustment is sometimes treated as an additional surgery that involves significant stress and often vagal responses during adjustment (e.g., nausea and vomiting) [34,35]. On the other hand, it is possible to perform adjustment as a one-stage procedure just after the main surgery, when the anesthetics are still working. Karaba et al. suggested the one-stage surgery technique in their report as being less stressful for the patient [36]. The same conclusions were provided by Cogen et al. [37]. Other authors provide 
modifications of AS technique to reduce the burden of adjustment. Nihalani et al. proposed short tag noose technique, which avoids the need for sedation in patients who do not require adjustment [38]. Robbins et al. described similar closed conjunctival delayed adjustable technique [39], and Budning et al. also similar short adjustable suture technique [40].

The advantages of AS use versus the relative potential discomfort of adjustment and the burden of reorganizing the operating theatre have to be balanced, and those patients who would benefit more from AS than NAS should be carefully selected.

The use of adjustable sutures in children also needs more comparative research. Ophthalmological centers that apply AS in children report good postoperative success rates. Again, these are mainly reports of postoperative outcomes rather than comparative studies [41,42]. In our analysis, one study strongly favored the use of AS in children, while another two papers did not report a statistically significant superiority of AS over NAS; however, the clinical tendency is to see better results with AS than NAS.

It is well-known from ophthalmological practice that not many surgeons routinely use the AS technique in children. Minors are usually less cooperative than adults, so performing the adjustment requires additional anesthesia, usually intravenous propofol or sometimes intranasal midazolam [43]. That is why, for some clinicians the whole procedure seems troublesome, and very young patients are considered not suitable for adjustment. However, this might be mainly due to a lack of experience with applying anesthesia in children, the belief that the procedure must be painful, and that successful outcomes require strict cooperation. Meanwhile, some surgeons perform use a single-stage adjustment surgery approach also in children. The use of general anesthesia with immediate postoperative adjustment requires a specific anesthetic technique, though. Usually, intravenous propofol is titrated in such situations $[27,44]$. Stopping propofol infusion enables the surgeon to perform the adjustment within minutes while the anesthetics are still working.

Without a doubt, the application of AS in children requires a certain organization of the operation theatre and involvement of a skillful anesthetic team. Probably, this is why it is not commonly applied in treating childhood strabismus. However, theoretically speaking, proper ocular alignment at a young age is expected to be beneficial for the development of the visual system and binocularity. Logically, the use of AS in children should provide better functional effects than that in adults. Many studies in the literature support benefits of early ocular alignment [45-48], however, the optimal age for strabismus surgery is still debatable $[49,50]$.

The analysis of comparative studies on AS versus NAS in cases of paretic and restrictive strabismus did not prove a statistically significant advantage inherent with the use of AS; however, again AS showed a clinical tendency to lead to better results. Usually, studies include a small number of cases, so it is difficult to conduct a proper statistical analysis. Besides, as paretic or restrictive strabismus is difficult to treat, very often, AS is used as a method of choice without involving a control group composed of NAS procedures.

Nevertheless, the use of AS in treating vertical deviations, especially in thyroid ophthalmopathy (TO), is controversial and, so far, there is no consensus regarding the use of AS in these disorders. One of the studies included in this review reported significant postoperative drift occurred in cases of vertical strabismus treated with AS [22]. Still, some surgeons advocate for the use of AS in the inferior rectus (IR) recession. Volpa et al. reported a large case series of 54 patients treated with AS due to vertical strabismus secondary to TO [51]. At a mean follow-up of 38 weeks, 35 patients (65\%) presented excellent results. Over-correction occurred in just $20 \%$ of cases ( $n=11$ patients). On the other hand, Kerr et al. revealed that over-correction in IR recession by AS is strongly correlated with TO and, thus, NAS should be used in such cases [52]. The same conclusion was provided by Shokida et al. and Schittkowski et al. [53,54]. Kushner suggests an interesting alternative for IR fixed recessions to avoid over-corrections involving applying semi-adjustable suture in such cases [55]. During this approach, the corners of the muscle are sutured firmly to the sclera, but its central part is placed using AS. Vazques et al. recommend pursuing under-correction when adjusting sutures in IR recessions [56]. 
In clinical practice, many surgeons use adjustable sutures as their method of choice for complicated cases of strabismus, such as paretic and restrictive strabismus, strabismus with unstable angle, or strabismus in high myopia [57-60]. A good example for that is the analysis of strabismus surgeries (2000-2008) performed at Moorfields Eye Hospital in patients older than 60 years of age indicated the use of AS occurred in 61\% cases ( $n=144$ patients) [61]. Major causes for surgery in this group included TO, sixth nerve palsy, and iatrogenic causes, but not comitant strabismus as seen in young individuals. Similar indications for strabismus surgery in patients over 60 years of age have been listed by Magramm et al. [62]. Paralytic and restrictive strabismus are common indications for the use of AS $[63,64]$. The AS technique can also be applied with success during superior oblique tendon surgery [65]. Some surgeons willingly use AS in cases of large-angle strabismus, when surgical tables are often misleading [66]. AS has been reported as an effective approach in cases of incomitant strabismus [67].

Available data prove that the AS technique in the hands of an experienced surgeon is a generally safe and comfortable procedure. Most of the operated patients do not complain of serious pain or discomfort during adjustment. A large study conducted in Germany questioned 113 patients who underwent the adjustment procedure more than 10 years before the survey and $89.4 \%$ of patients either did not remember the adjustment or did not have any complaints about the procedure [68].

The AS procedure does not affect conjunctival healing significantly. Studies have suggested that eye redness post-surgery not persist significantly longer in eyes operated on with this technique relative to those who underwent NAS [69].

The AS technique, however, does requires some special attention. There exists a potential for drift toward under-correction with the use of this procedure so, generally, the adjustment should include some over-correction [70]. Some studies have supported, however, that the drift seen in AS is not larger than that which occurs with NAS [30].

Importantly, the present review does not support the superiority of AS over NAS in the majority of strabismus patients; however, the author hopes not to discourage ophthalmologists from using AS. On the contrary, the author supports gathering further results from everyday clinical practice and rationale to support the use of AS in complicated forms of strabismus, especially reoperations and unpredictable cases. More research and opinion-sharing is needed in the treatment of childhood strabismus with AS, as the author believes that increasing the frequency of use of this technique in minors is a technical concern rather than a substantial one.

\section{Conclusions}

The analysis of available research did not provide an univocal answer to support that AS is superior to NAS in simple comitant strabismus. More precise selection of patients for the AS surgery could provide the data on benefits of this form of surgery. Research aimed at determining the optimal group(s) of patients with strabismus who would benefit most from AS over NAS should be carried out. The use of AS in children requires the specific organization of the operating theatre and anesthetic team. Further research is needed to confirm adequate long-term functional benefits of AS use in children.

Funding: This research received no specific grant from any funding agency in the public, commercial or not-for-profit sectors.

Conflicts of Interest: The author reports no conflict of interest. The author alone is responsible for the content and writing of the paper.

\section{References}

1. Jampoloskry, A.L. Strabismus reoperation techniques. Trans. Am. Acad. Ophthalmol. Otolaryngol. 1975, 79, 704-711.

2. Peragallo, J.H.; Bruce, B.B.; Hutchinson, A.K.; Lenhart, P.D.; Biousse, V.; Newman, N.J.; Lambert, S.R. Predictors of good motor and sensory outcomes following strabismus surgery for patients with third nerve palsies. Neuroophthalmology 2014, 39, 12-16. [CrossRef] [PubMed] 
3. Mazow, M.L.; Fletcher, J. Selection of patients and results of 25 years of topical anesthesia and adjustable suture surgery. Am. Orthopt. J. 2013, 63, 85-91. [CrossRef] [PubMed]

4. Repka, M.X.; Lum, F.; Burugapalli, B. Strabismus, strabismus surgery, and reoperation rate in the United States: Analysis from the IRIS registry. Ophthalmology 2018, 125, 1646-1653. [CrossRef] [PubMed]

5. DiAntonio, C. Let's get it straight: The nursing implications of adjustable sutures in the adult strabismus patient. Insight 2005, 30, 12-15. [PubMed]

6. Vasconcelos, G.C.; Guyton, D.L. Adjustable sutures in strabismus surgery: Why surgeons either love them or hate them after three decades. Arq. Bras. Oftalmol. 2014, 77, 5-6. [CrossRef] [PubMed]

7. Kamal, A.M.; Abozeid, D.; Seif, Y.; Hassan, M. A comparative study of adjustable and non-adjustable sutures in primary horizontal muscle surgery in children. Eye 2016, 30, 1447-1451. [CrossRef] [PubMed]

8. Babu, S.; Goel, Y.; Chaudhary, R.B.; Rastogi, A.; Agarwal, R.; Dhiman, S.; Kumar, P.; Bharadwaj, A. Comparison of adjustable sutures versus nonadjustable sutures in intermittent exotropia. Eur. J. Ophthalmol. 2018, 28, 264-267. [CrossRef]

9. Agrawal, S.; Singh, V.; Singh, P. Adjustable recessions in horizontal comitant strabismus: A pilot study. Indian J. Ophthalmol. 2015, 63, 611-613. [CrossRef]

10. Mireskandari, K.; Cotesta, M.; Schofield, J.; Kraft, S.P. Utility of adjustable sutures in primary strabismus surgery and reoperations. Ophthalmology 2012, 119, 629-633. [CrossRef]

11. Zhang, M.S.; Hutchinson, A.K.; Drack, A.V.; Cleveland, J.; Lambert, S.R. Improved ocular alignment with adjustable sutures in adults undergoing strabismus surgery. Ophthalmology 2012, 119, 396-402. [CrossRef] [PubMed]

12. Ferdi, A.; Kelly, R.; Logan, P.; Dooley, I. Outcomes of adjustable strabismus surgery in an Irish University Hospital. Int. Ophthalmol. 2017, 37, 1215-1219. [CrossRef] [PubMed]

13. Liebermann, L.; Hatt, S.R.; Leske, D.A.; Holmes, J.M. Adjustment versus no adjustment when using adjustable sutures in strabismus surgery. J. Am. Assoc. Pediatric Ophthalmol. Strabismus 2013, 17, 38-42. [CrossRef] [PubMed]

14. Park, Y.C.; Chun, B.Y.; Kwon, J.Y. Comparison of the stability of postoperative alignment in sensory exotropia: Adjustable versus non-adjustable surgery. Korean J. Ophthalmol. 2009, 23, 277-280. [CrossRef] [PubMed]

15. Mireskandari, K.; Schofield, J.; Cotesta, M.; Stephens, D.; Kraft, S.P. Achieving postoperative target range increases success of strabismus surgery in adults: A case for adjustable sutures? Br. J. Ophthalmol. 2015, 99, 1697-1701. [CrossRef] [PubMed]

16. Leffler, C.T.; Pariyadath, A. Strabismus surgery among Medicare beneficiaries: Imputed rates of reoperation in the same calendar year. Digit. J. Ophthalmol. 2016, 22, 6-11. [CrossRef] [PubMed]

17. Leffler, C.T.; Vaziri, K.; Cavuoto, K.M.; McKeown, C.A.; Schwartz, S.G.; Kishor, K.S.; Pariyadath, A. Strabismus surgery reoperation rates with adjustable and conventional sutures. Am. J. Ophthalmol. 2015, 160, 385-390. [CrossRef]

18. Tripathi, A.; Haslett, R.; Marsh, I.B. Strabismus surgery: Adjustable sutures-good for all? Eye 2003, 17, 739-742. [CrossRef]

19. Kassem, A.; Xue, G.; Gandhi, N.B.; Tian, J.; Guyton, D.L. Adjustable suture strabismus surgery in infants and children: A 19-year experience. J. Am. Assoc. Pediatric Ophthalmol. Strabismus 2018, 22, 174-178. [CrossRef]

20. Leffler, C.T.; Vaziri, K.; Schwartz, S.G.; Cavuoto, K.M.; McKeown, C.A.; Kishor, K.S.; Janot, A.C. Rates of reoperation and abnormal binocularity following strabismus surgery in children. Am. J. Ophthalmol. 2016, 39, 12-16. [CrossRef]

21. Karhanová, M.; Vláčil, O.; Sín, M.; Marešová, K. Adjustable versus non-adjustable sutures in strabismus surgery in patients with thyroid ophthalmopathy. Cesk Slov. Oftalmol. 2012, 68, 207-213. [PubMed]

22. Peragallo, J.H.; Velez, F.G.; Demer, J.L.; Pineles, S.L. Postoperative drift in patients with thyroid ophthalmopathy undergoing unilateral inferior rectus muscle recession. Strabismus 2013, 21, 23-28. [CrossRef] [PubMed]

23. Kraus, D.J.; Bullock, J.D. Treatment of thyroid ocular myopathy with adjustable and nonadjustable suture strabismus surgery. Trans. Am. Ophthalmol. Soc. 1993, 91, 67-79. [PubMed]

24. Hassan, S.; Haridas, A.; Sundaram, V. Adjustable versus non-adjustable sutures for strabismus. Cochrane Database Syst. Rev. 2018, 28, 206-211. [CrossRef] [PubMed]

25. Weston, B.; Enzenauer, R.W.; Kraft, S.P.; Gayowsky, G.R. Stability of the postoperative alignment in adjustable-suture strabismus surgery. J. Pediatr. Ophthalmol. Strabismus 1991, 28, 206-211. [PubMed] 
26. Agnello, R. Adjustable sutures in strabismus surgery: A personal series of cases. Aust. N. Z. J. Ophthalmol. 1986, 14, 143-153. [CrossRef]

27. Pratt-Johnson, J.A. Adjustable-suture strabismus surgery: A review of 255 consecutive cases. Can. J Ophthalmol. 1985, 20, 105-109.

28. McNeer, K.W. Adjustable sutures of the vertical recti. J. Pediatr Ophthalmol. Strabismus 1982, 19, $259-264$.

29. Razmjoo, H.; Attarzadeh, H.; Karbasi, N.; Najarzadegan, M.R.; Salam, H.; Jamshidi, A. A survey of outcome of adjustable suture as first operation in patients with strabismus. Adv. Biomed. Res. 2014, 24, 97-102.

30. Keech, R.V.; Scott, W.E.; Christensen, L.E. Adjustable suture strabismus surgery. J. Pediatr. Ophthalmol. Strabismus 1987, 24, 97-102.

31. Franklin, S.R.; Hiatt, R.L. Adjustable sutures in strabismus surgery. Ann Ophthalmol. 1989, 21, $285-289$. [PubMed]

32. Pratt-Johnson, J.A. Complicated strabismus and adjustable sutures. Aust. N. Z. J. Ophthalmol. 1988, 16, 87-92. [CrossRef] [PubMed]

33. Kenneth, W. Color Atlas of Ophthalmic Surgery; Strabismus, J.B., Ed.; Lippincott Company: Philadelphia, PA, USA, 1991; pp. 87-88.

34. Eustis, H.S.; Eiswirth, C.C.; Smith, D.R. Vagal responses to adjustable sutures in strabismus correction. Am. J. Ophthalmol. 1992, 114, 307-310. [CrossRef]

35. Apt, L.; Isenberg, S.J. Oculocardiac reflex during manipulation of adjustable sutures after strabismus surgery. Am. J. Ophthalmol. 1987, 104, 551-553. [CrossRef]

36. Karaba, V.L.; Elibol, O. One-stage vs. two-stage adjustable sutures for the correction of esotropia. Strabismus 2004, 12, 27-34. [CrossRef] [PubMed]

37. Cogen, M.S.; Guthrie, M.E.; Vinik, H.R. The immediate postoperative adjustment of sutures in strabismus surgery with comaintenance of anesthesia using propofol and midazolam. J. Am. Assoc. Pediatric Ophthalmol. Strabismus 2002, 6, 241-245. [CrossRef] [PubMed]

38. Nihalani, B.R.; Whitman, M.C.; Salgado, C.M.; Loudon, S.E.; Hunter, D.G. Short tag noose technique for optional and late suture adjustment in strabismus surgery. Arch. Ophthalmol. 2009, 127, 1584-1590. [CrossRef]

39. Robbins, S.L.; Granet, D.B.; Burns, C.; Freeman, R.S.; Eustis, H.S.; Yafai, S.; Cruz, F.; Danylyshyn-Adams, K.; Langham, K. Delayed adjustable sutures: A multicentred. clinical review. Br. J. Ophthalmol. 2010, 94, 1169-1173. [CrossRef]

40. Budning, A.S.; Day, C.; Nguyen, A. The short adjustable suture. Can. J. Ophthalmol. 2010, 45, 359-362. [CrossRef]

41. Franco, F.; Bolletta, E.; Mancioppi, S.; Franco, E.; Migliorelli, A.; Perri, P. Topical anesthesia in children with intraoperative adjustable strabismus surgery. J. Pediatr. Ophthalmol. Strabismus. 2019, 56, 173-177. [CrossRef]

42. Awadein, A.; Sharma, M.; Bazemore, M.G.; Saeed, H.A.; Guyton, D.L. Adjustable suture strabismus surgery in infants and children. J. Am. Assoc. Pediatric Ophthalmol. Strabismus 2008, 12, 585-590. [CrossRef] [PubMed]

43. Hakim, O.M.; El-Hag, Y.G.; Haikal, M.A. Releasable adjustable suture technique for children. J. Am. Assoc. Pediatric Ophthalmol. Strabismus 2005, 9, 386-390. [CrossRef] [PubMed]

44. Ohmi, G.; Hosohata, J.; Okada, A.A.; Fujikado, T.; Tanahashi, N.; Uchida, I. Strabismus surgery using the intraoperative adjustable suture method under anesthesia with propofol. Jpn. J. Ophthalmol. 1999, 43, 522-525. [CrossRef]

45. Ing, M.R. The timing of surgical alignment for congenital (infantile) esotropia. J. Pediatr. Ophthalmol. Strabismus 1999, 36, 61-68. [PubMed]

46. Yoo, E.J.; Kim, S.H. Optimal surgical timing in infantile exotropia. Can, J. Ophthalmol. 2014, 49, 358-362. [CrossRef]

47. Singh, A.; Sharma, P.; Singh, D.; Saxena, R.; Sharma, A.; Menon, V. Evaluation of FD2 (Frisby Davis distance) stereotest in surgical management of intermittent exotropia. Br. J. Ophthalmol. 2013, 97, 1318-1321. [CrossRef]

48. Sarwar, H.; Waqar, S. Surgery for infantile esotropia: Is timing everything? J. Perioper. Pract. 2013, 23, 107-109. [CrossRef]

49. Korah, S.; Philip, S.; Jasper, S.; Antonio-Santos, A.; Braganza, A. Strabismus surgery before versus after completion of amblyopia therapy in children. Cochrane Database Syst. Rev. 2014, 38, 247-252. [CrossRef]

50. Speeg-Schatz, C.; Gottenkiene, S.; Sauer, A.; Roth, A. Surgery for convergent strabismus in childhood: Why and when? J. Fr. Ophtalmol. 2015, 38, 247-252. [CrossRef] 
51. Volpe, N.J.; Mirza-George, N.; Binenbaum, G. Surgical management of vertical ocular misalignment in thyroid eye disease using an adjustable suture technique. J. Am. Assoc. Pediatric Ophthalmol. Strabismus 2012, 16, 518-522. [CrossRef]

52. Kerr, N.C. The role of thyroid eye disease and other factors in the overcorrection of hypotropia following unilateral adjustable suture recession of the inferior rectus (an American Ophthalmological Society thesis). Trans. Am. Ophthalmol. Soc. 2011, 109, 168-200. [PubMed]

53. Shokida, M.F.; Gabriel, J.; Sanchez, C. Safety stitch: A modification to postoperatively adjustable suture strabismus surgery of the inferior rectus muscle. Binocul. Vis. Strabismus Q. 2007, 22, 210-215. [PubMed]

54. Schittkowski, M.; Fichter, N.; Guthoff, R. Strabismus surgery in Grave's disease-Dose-effect relationships and functional results. Klin. Monbl Augenheilkd. 2004, 221, 941-947. [CrossRef] [PubMed]

55. Kushner, B.J. An evaluation of the semiadjustable suture strabismus surgical procedure. J. Am. Assoc. Pediatric Ophthalmol. Strabismus 2005, 8, 481-487, Erratum in J. Am. Assoc. Pediatric Ophthalmol. Strabismus 2005, 9, 204. [CrossRef]

56. Vazquez, C.W.; Muñoz, M. Overcorrection after adjustable suture suspension- recession of the inferior rectus muscle in non-thyroid eye disease. Binocul. Vis Strabismus Q. 1999, 14, 103-106.

57. Broniarczyk-Loba, A.; Nowakowska, O. Own experience with the use of adjustable sutures in various types of strabismus operations. Klin. Oczna. 1998, 100, 305-309.

58. Fells, P. The use of adjustable sutures. Trans. Ophthalmol. Soc. UK 1981, 101, 279-283.

59. Louis, M.; Flanders, M.; Chankowsky, J.; Lindley, S.; Polomeno, R. Acquired restrictive strabismus and high axial myopia: Diagnosis and management. Can. J. Ophthalmol. 2009, 44, 437-440. [CrossRef]

60. Estermann, S.S.; Mojon, D. Opinions of German-speaking experts about strabismus surgery. Klin. Monbl Augenheilkd. 2009, 226, 475-484. [CrossRef]

61. Maino, A.P.; Dawson, E.M.; Lee, J.P. Strabismus surgery in the over 60s-An update. Strabismus 2011, 19, 1-4. [CrossRef]

62. Magramm, I.; Schlossman, A. Strabismus in patients over the age of 60 years. J. Pediatr. Ophthalmol. Strabismus 1991, 28, 28-31. [PubMed]

63. Gonzalez, C.; Chen, H.H.; Ahmadi, M.A. Sherrington innervational surgery in thetreatment of chronic sixth nerve paresis. Binocul. Vis. Strabismus Q. 2005, 20, 159-166. [PubMed]

64. Thacker, N.M.; Velez, F.G.; Bhola, R.; Britt, M.T.; Rosenbaum, A.L. Lateral rectusresections in divergence palsy: Results of long-term follow-up. J. Am. Assoc. Pediatric Ophthalmol. Strabismus 2005, 9, 7-11. [CrossRef] [PubMed]

65. Goldenberg-Cohen, N.; Tarczy-Hornoch, K.; Klink, D.F.; Guyton, D.L. Postoperative adjustable surgery of the superior oblique tendon. Strabismus 2005, 13, 5-10. [CrossRef]

66. Currie, Z.I.; Shipman, T.; Burke, J.P. Surgical correction of large-angle exotropiain adults. Eye 2003, 17, 334-339. [CrossRef]

67. Bock, C.J., Jr.; Buckley, E.G.; Freedman, S.F. Combined resection and recession of a single rectus muscle for the treatment of incomitant strabismus. J. Am. Assoc. Pediatric Ophthalmol. Strabismus 1999, 3, 263-268. [CrossRef]

68. Wabbels, B.; Förster, J.; Roggenkämper, P. Long-term follow-up and patient satisfaction of squint surgery with adjustable sutures. Klin. Monbl Augenheilkd. 2013, 230, 983-989.

69. Escardó-Paton, J.A.; Harrad, R.A. Duration of conjunctival redness following adult strabismus surgery. J. Am. Assoc. Pediatric Ophthalmol. Strabismus 2009, 13, 583-586. [CrossRef]

70. Isenberg, S.J.; Abdarbashi, P. Drift of ocular alignment following strabismus surgery. Part 2: Using adjustable sutures. Br. J. Ophthalmol. 2009, 93, 443-447. [CrossRef]

(C) 2020 by the author. Licensee MDPI, Basel, Switzerland. This article is an open access article distributed under the terms and conditions of the Creative Commons Attribution (CC BY) license (http://creativecommons.org/licenses/by/4.0/). 